\section{Liberal development}

\section{P.D. Henderson}

Economic Development: Theory, Policy, and International Relations.

By Ian Little.

Basic Books: 1982. Pp.452. \$20, £12.

DURING the quarter of a century that ended in 1973, the world economy grew at a rate which was both unprecedented and unforeseen. Moreover, the rise in output and average material prosperity was not only more rapid than in the past, but more widely diffused. In terms of output, it is the growth of developing countries in particular which has distinguished the postWar era. Furthermore, in most of these countries the momentum of growth was well sustained for several years after the turning point of 1973, when the West succumbed to apparently chronic "stagflation".

On the world political scene the developing countries, their numbers swollen by the dissolution of all but one of the past colonial empires, have become established as a distinct and surprisingly cohesive pressure group. Since 1961 they have been organized for negotiating purposes in the so-called "Group of 77", which now includes some 120 members. As such, they have consistently pressed the rich industrial countries, through the medium of what is now called the North-South dialogue, to agree to a package of international economic reforms. The purpose of these is to redress what is seen as a bias of the existing system against the developing countries, which by holding back their progress perpetuates international inequality and injustice. Since 1974 the Group of 77 have argued for a "New International Economic Order". However, as Ian Little points out in his remarkable new book, the main ingredients of this programme go back as far as 1946, to the early post-War discussions on the form of the international economic system.

A related post-War phenomenon has been the emergence, within the world of academic economics, of a new field of study. Its separate status has been a matter not just of geography, but of underlying methods and assumptions. A consensus emerged that a different approach, a distinctive model or framework of thought, should be applied to the developing countries. To construct this framework, and apply it to particular countries and problems, has been seen as the special task of development economics.

\section{Third age}

The final volume in the trilogy Aging: $A$ Challenge to Science and Society, has been published by Oxford University Press. Subtitled Behavioural Sciences and Conclusion, the book costs $£ 40$. For review of Vols 1 and 2 see Nature 296, 179 (1982).
All three aspects of recent history - the record and its interpretation, the effects on the developing countries of the international trading and monetary regime, and the evolution of economists' perceptions of reality - are brought out in Little's study. In his preface, he describes the book as "a rather comprehensive, critical survey of development economics", but in fact it is much more than that. Rather, it is an extended and masterly personal review of the leading issues in economic development, development economics and international economic relations. Its unity derives not from a particular emphasis on the ideas of economists, but from the author's own view of the world. The book explicitly sets out a "neo-classical" or "liberal" conception of development, which embodies both a set of values and a vision of the economic process. As to the values, development is defined in terms of the traditional objectives of liberal economics, namely material prosperity and a more equal distribution of income and wealth. Thus it is the welfare of individuals, both living and unborn, that is to count. This goes with a concern for personal liberty, as an additional though related value.

As regards the working of economic systems, the neo-classical approach sees markets and prices as providing, at least potentially, appropriate signals for people and organizations. A market economy serves a dual cause. It safeguards freedom of choice, and it makes for a more efficient allocation of resources. Economic liberals are therefore sceptical about the benefits claimed for centralized planning and administrative modes of regulation and control. To use Paul Streeten's not entirely respectful term, they are "price mechanists".

This approach is seen as generally valid, for rich countries and poor alike. One corollary is that as a rule countries will benefit from the adoption of liberal trade and payments policies, by themselves as well as others. What Little calls the "resurgence of neo-classical economics after 1960 "' in relation to issues of development mainly arose from two related lines of thought. One was a restatement of the case for free trade in a form which is more precise and less open to qualification. The other was a growing realization, based on observation of and research into the development process research in which Little himself played a leading part - that countries with open trade regimes had gained from this choice, while those with restrictive policies had suffered. In the former category, the outstanding cases are Hong Kong, South Korea, Singapore and Taiwan. These have achieved not only amazingly high growth rates but also a reasonably even distribution of the fruits of growth. In part at least, this can be attributed to the adoption of open trade policies, which have made the process of growth not only faster but also more labour-intensive.

The liberal approach is at variance with three other bodies of doctrine which are surveyed at length by Little, of ten in severely critical terms. One is the orthodox development economics of the 1940s and 1950s. A second and more recent growth is the "new radicalism", in both Marxist and non-Marxist forms. Finally, there is the stance taken by the Group of 77 and their Western sympathizers, such as Willi Brandt and Edward Heath. This forms part of the subject-matter of the final section of the book, which deals with international economic reform and NorthSouth relations.

The argument throughout the book is lucid, ordered and informed. From the table of contents, one might suppose that much of it is mere exposition of different schools of thought. In fact, the author's treatment is more personal and more complex than the headings suggest. At each stage, ideas and events are placed in the context of his own view of the development process, which emerges from the volume as a whole rather than as an isolated statement. Despite its length, the book is not in the least discursive or repetitive, and at various points the treatment could with advantage have been made longer and more explicit. Little has something interesting and worth while to say on a wide range of issues and topics; even the footnotes, of which there are over 700 , include a good many statements that bear pondering.

To my mind, the book's chief limitations are two, which are linked one to another. First, a lot of space is given to the ideas of academic economists. Not only does this make the argument less accessible to the general reader, but it looks odd when one bears in mind the fact - fully recognized by Little - that the influence of these ideas on actual policies and outcomes is uncertain, and probably rather slight. Second, not much is said about how and why government policies came to be what they were. Little is well aware that governments do not necessarily see themselves as concerned with development in his sense that is, "a rise in the present value of average (weighted) consumption per head"' (p.6). At various points he mentions in passing the influence of other motives, objectives and preoccupations. But like most economists, he takes the matter no further. Thus a central question in the interpretation of events is dealt with by setting it on one side.

Perhaps it might have been better if instead of writing one long book on economic development, Ian Little had produced two medium-sized ones, for rather different though overlapping audiences. None the less, this is a most impressive piece of work, which will be read with profit by those who reject the author's conception of development as well as those who share it.

P.D. Henderson is a Professor in the Department of Political Economy at University College London. 